\title{
Распределение примесей в мультикристаллическом кремнии, выращенном из UMG-кремния методом Бриджмена
}

\author{
С.М. Пещерова ${ }^{1)}$, Р.В. Пресняков ${ }^{1)}$, А.И. Непомнящих ${ }^{1)}$, Н.В. Клушина ${ }^{1,2)}$ \\ ${ }^{1}$ Институт геохимии им. А.П. Виноградова СО РАН, \\ 664033 г. Иркутск, ул. Фаворского, д.1 "А" \\ ${ }^{2}$ Иркутский государственный университет, 664003, ул. Карла Маркса, д.1 \\ эл.nочта: spescherova@mail.ru
}

DOI 10.34077/RCSP2019-35

В последние годы в технологии фотоэлектрических преобразователей на основе мультикристаллического кремния $(\mathrm{mc}-\mathrm{Si})$ существенной альтернативой стало использование $\mathrm{n}$-типа проводимости в качестве материала исходной подложки наряду с традиционным р-типом. Показано, что в слитках $\mathrm{n}$ типа высокие значения времени жизни неравновесных носителей заряда (вплоть до 1 мс) обусловлены не столько фундаментальным отличием электронов от дырок, сколько отсутствием глубоких уровней, характерных именно для mc-Si p-типа [1]. Например, это уровни, связанные с образованием комплексов B-O и Fе-В. Актуальной альтернативой, снижающей себестоимость кремниевых пластин, является использование металлургического кремния высокой чистоты (UMG$\mathrm{Si}, 5 \mathrm{~N}-6 \mathrm{~N})$ в качестве исходной для выращивания слитков загрузки. Однако, не все присутствующие в нём примеси и не всегда образуют монотонно возрастающий профиль распределения, соответствующий конкретному значению эффективного распределения $(<1)$ конкретной примеси [2]. Помимо начальной концентрации примеси, скорости и формы фронта кристаллизации, процессов в расплаве, необходимо учитывать еще и зёренно-граничную структуру слитка, распределение дислокаций. Неравномерность распределения примесей в $\mathrm{mc}-\mathrm{Si}$ в существенной мере связана с процессами сегрегации примесей на межзёренных границах общего типа и дислокациях [3]. В настоящей работе мы рассматриваем особенности взаимодействия 19 элементов примесей между собой в зависимости от формируемой макроструктуры слитка. Процессы сегрегации примесей связаны не только с границами общего типа и дислокациями, но и с распределением их в виде микровключений в зёрнах [4]. Причем, микровключения различных составов по-разному влияют на распределение времени жизни ННЗ в объеме слитка мультикремния. А состав микровключения, в свою очередь, связан с кристаллографическими особенностями зерна: более плотноупакованные относительно плоскости фронта кристаллизации зёрна (зёрна с высокой ретикулярной плотностью) существенно меньше содержат микровключений и дислокаций, чем зёрна с более низкой ретикулярной плотностью. Влиять на процессы распределения примесей в процессе кристаллизации, таким образом, представляется возможным благодаря обеспечению особых тепловых и скоростных режимов направленной кристаллизации. Это перспективное направление исследований позволит достичь высокой эффективности фотоэлектропреобразователей на основе мультикремния и существенно снизить их себестоимость за счёт использования в качестве исходного сырья UMG-Si.

\section{Лumepamypa}

[1] J. Schön, F. Schindler, W. Kwapil et al. Identification of the most relevant metal impurities in mc n-type silicon for solar cells. Solar Energy Materials and Solar Cells 142:107-115, DOI:

10.1016/j.solmat.2015.06.028.

[2] M. C. Schubert, J. Schön, F. Schindler et al. Impact of Impurities From Crucible and Coating on mcSilicon Quality - the Example of Iron and Cobalt, IEEE Journal of Photovoltaics 3(4):1250-1258, 2013, DOI: 10.1109/JPHOTOV.2013.2279116.

[3] S. J. Bo, S. S. Matsushima. Effects of crystal defects and their interactions with impurities on electrical properties of multicrystalline Si Effects of crystal defects and their interactions with impurities on electrical properties of multicrystalline Si, Journal of Applied Physics 113(133503), 2013, DOI: 10.1063/1.4798600.

[4] С.М. Пещерова, Е.Б. Якимов, А.И. Непомнящих, Л.А. Павлова, О.В. Феклисова, Орлов В.И., Р.В. Пресняков. Зависимость объемных электрофизических свойств мультикремния от параметров разориентации зёрен, Физика и техника полупроводников, 2019, том 53, вып. 1, с. 59-64. 